\title{
Effects of exogenous growth hormone administration on dexamethasone-induced growth impairment in adolescent male rats
}

\author{
MYUNG-GYOU KIM ${ }^{1}$, JEONG-SEOK OH ${ }^{1}$, HYE KYUNG KIM ${ }^{2}$ and KANG-HYUN LEEM ${ }^{1}$ \\ ${ }^{1}$ College of Korean Medicine, Semyung University, Jecheon, Chungcheongbuk-do 27136; \\ ${ }^{2}$ Department of Food and Biotechnology, Hanseo University, Seosan, Chungcheongnam-do 31962, Republic of Korea
}

Received July 5, 2016; Accepted May 5, 2017

DOI: $10.3892 /$ etm.2017.5017

\begin{abstract}
Growth impairment (GI) is one of the adverse effects of dexamethasone (DXM), and growth hormone (GH) has been used clinically to improve GI. The present study aimed to evaluate the manner in which DXM disturbs the growth rate of longitudinal bones, and the recovery effects of GH on DXM-induced GI in the longitudinal bones of adolescent male rats. In the first experiment, DXM $(0,0.5,1,2$ and $5 \mathrm{mg} / \mathrm{kg}$ ) was administered subcutaneously to identify a potential dose-dependent activity and calculate the median effective dose (ED50) of DXM-induced GI. The ED50 was identified to be $1.15 \mathrm{mg} / \mathrm{kg}$. In the second experiment, $\mathrm{GH}(0,2.5,5$ and $10 \mathrm{mg} / \mathrm{kg}$ ) with $1.15 \mathrm{mg} / \mathrm{kg}$ DXM was injected subcutaneously to assess the recovery effects of GH on DXM-induced GI. The grow th rates of the longitudinal bones, total height of the growth plate, local mRNA expressions of insulin-like growth factor 1 (IGF-1), GH receptor (GHR) and IGF-1 receptor (IGF-1R), and local protein expression of IGF-1 were measured to evaluate the recovery effects of GH on DXM-induced GI. The local expressions of IGF-1, GHR and IGF-1R mRNA, and IGF-1 protein were measured using quantitative polymerase chain reaction following laser microdissection and antigen-specific immunohistochemistry, respectively. GH administration partially recovered DXM-induced GI in the longitudinal bones
\end{abstract}

Correspondence to: Professor Kang-Hyun Leem, College of Korean Medicine, Semyung University, 65 Semyeong-ro, Jecheon, Chungcheongbuk-do 27136, Republic of Korea

E-mail: heavenok@dreamwiz.com

Abbreviations: DXM, dexamethasone; ED50, median effective dose; GAPDH, glyceraldehyde 3-phosphate dehydrogenase; GC, glucocorticoid; GH, growth hormone; GHR, growth hormone receptor; GHRH, growth hormone-releasing hormone; GI, growth impairment; IGF-1, insulin-like growth factor 1; IGF-1R, insulin-like growth factor 1 receptor; LMD, laser microdissection; RT-qPCR, reverse transcription-quantitative polymerase chain reaction

Key words: dexamethasone, growth hormone, insulin-like growth factor 1, bone growth, growth impairment, growth plate and growth plate. GH significantly increased the levels of IGF-1, GHR and IGF-1R mRNA in the proliferative zone of the control group $(\mathrm{P}<0.05)$, whereas it failed to increase them in the proliferative zone of the DXM-treated group. Furthermore, GH increased the levels of IGF-1, GHR and IGF-1R mRNA in the hypertrophic zone of both the vehicle and DXM-treated groups $(\mathrm{P}<0.05)$. Immunohistochemical analysis of IGF-1 protein expression revealed a similar pattern to that of IGF-1 mRNA. These results suggest that increased GH insensitivity in the proliferative zone of the growth plate, induced by DXM, leads to GI in longitudinal bones. Thus, combined administration of $\mathrm{GH}$ with $\mathrm{GH}$ insensitivity-alleviating medications may be more effective in the treatment of DXM-induced GI.

\section{Introduction}

Skeletal growth impairment (GI) commonly arises in growing animals administered with glucocorticoid (GC) (1) and children with chronic inflammatory diseases undergoing long-term GC therapy $(2,3)$. Numerous factors, including childhood malnutrition, chronic inflammation and prolonged use of GC, may contribute to growth failure (4). Among those factors, GC itself has been reported to cause GI even in the absence of chronic inflammation or malnutrition (5).

Dexamethasone (DXM) is a potent synthetic member of the GC class of steroids. It is widely used to treat autoimmune diseases, inflammation and cancer due to its anti-inflammatory and immunosuppressive effects (6,7). Although it is included on the World Health Organization list of essential medicines for a basic health system (8), DXM is a potent inhibitor of longitudinal bone growth, and GI is established as one of its adverse effects $(5,9)$. DXM also exerts direct effects on chondrocytes of the growth plate, thereby augmenting the insensitivity to growth hormone $(\mathrm{GH})$ and insulin-like growth factor 1 (IGF-1) by reducing $\mathrm{GH}$ receptor (GHR) and IGF-1 receptor (IGF-1R) expression $(10,11)$.

Longitudinal bone growth is completed through the proliferation and differentiation of chondrocytes in the growth plate at the ends of long bones (12). It makes rapid progress during prenatal and early postnatal life, gradually weakens with age, and eventually ceases during adolescence (12). The rate of longitudinal bone growth is tightly regulated by numerous 
cytokines and endocrine hormones, including GH, IGF-1, thyroid hormone, GCs, androgens and estrogens (13). Growth plate maturation ultimately culminates in endochondral ossification following puberty, resulting in fusion of the epiphysis to the metaphysis (14).

$\mathrm{GH}$, which acts as a potent anabolic agent, is a peptide hormone secreted by the pituitary gland, and stimulates growth and cell reproduction (14). It has been used clinically to promote linear growth in GH-deficient children and adults $(15,16)$, and is prescribed to treat childhood growth disorders and adult GH deficiency (17). Furthermore, in some clinical trials (18-21), exogenous $\mathrm{GH}$ was administered to treat children with severe GI who had been undergoing long-term GC therapy due to chronic inflammatory disease. However, the response to GH varied depending on diverse factors, including nutrition and adrenocortical hormones. Thus, an in-depth assessment into the effect of GH on DXM-induced GI is required.

Given that DXM elevates peripheral insensitivity to GH $(10,11)$, the present study postulated that exogenous GH administration may recover DXM-induced GI. Previous clinical research (22) reported that GH therapy may counterbalance the growth suppressing effects of GCs. The growth promoting effect of GH on DXM-induced GI, however, is not yet supported by sufficient in vivo evidence. The present study aimed to identify the manner in which DXM disturbs the growth rate of longitudinal bones, and to investigate the potential recovery effects of GH on DXM-induced GI. The present results may provide insight into the therapeutic effects of exogenous $\mathrm{GH}$ administration for the treatment of DXM-induced GI.

\section{Materials and methods}

Animals. The longitudinal bone growth of 3-week-old male Sprague-Dawley rats $(\mathrm{n}=110,70 \pm 2 \mathrm{~g}$; Samtako Co., Ltd., Seoul, Korea) was measured using Hasson's method (23) with some modifications, as described below. The experimental procedures were performed in accordance with protocols approved by the Institutional Animal Care and Use Committee at Semyung University (Jecheon, Korea; approval no. smecae 09-06-01). All rats were housed in the same animal holding room with standard laboratory animal environment, under a 12-h light/dark cycle in a controlled environment: temperature, $21 \pm 2^{\circ} \mathrm{C}$ and humidity, $50 \pm 20 \%$. In a preliminary experiment, the rats were randomly divided into five groups $(n=10$ in each group): Vehicle (saline-administered control) and four DXM-treated groups $(0.5,1,2$ and $5 \mathrm{mg} / \mathrm{kg}$; Sigma-Aldrich; Merck KGaA, Darmstadt, Germany). In a follow-up experiment, a different cohort of rats was randomly divided into six groups ( $\mathrm{n}=10$ in each group): Vehicle (saline-administered control), GH-administration group ( $2.5 \mathrm{mg} / \mathrm{kg}$; Sigma-Aldrich; Merck KGaA), DXM-treated group $(1.15 \mathrm{mg} / \mathrm{kg})$ with no $\mathrm{GH}$, and three DXM + GH-treated groups $(1.15 \mathrm{mg} / \mathrm{kg} \mathrm{DXM}+2.5$, 5 or $10 \mathrm{mg} / \mathrm{kg} \mathrm{GH}$ ). In both the preliminary and follow-up experiments, vehicle, DXM and/or GH were administered subcutaneously, once a day for five consecutive days. On the fourth day of the experiment, all rats were intraperitoneally injected with $10 \mathrm{mg} / \mathrm{kg}$ calcein (Sigma-Aldrich; Merck KGaA) in saline for measurement of bone growth length. Animals were anesthetized by inhalation of diethyl ether $(5 \mathrm{ml} / \mathrm{l}$ air;
Sigma-Aldrich; Merck KGaA) and sacrificed by decapitation $24 \mathrm{~h}$ after the calcein injection for subsequent dissection of their proximal tibias. The body weight was measured every 5 consecutive days in both experiments. The ED50 of DXM in the first experiment was employed as the DXM concentration in the second experiment, and was calculated using GraphPad Prism software (version 6; GraphPad Software, Inc., La Jolla, CA, USA) in accordance with the manufacturer's instructions.

Measurement of longitudinal bone growth width and growth plate height. The dissected tibias were fixed in $0.1 \mathrm{M}$ phosphate-buffered formalin for $2 \mathrm{~h}$ at room temperature, then decalcified in Decalcifying Solution-Lite (Sigma-Aldrich; Merck KGaA) and dehydrated by immersion in $30 \%$ sucrose for 1 day at $4^{\circ} \mathrm{C}$. The dehydrated bones were frozen and sectioned longitudinally at sagittal sections of the proximal part with a thickness of $40 \mu \mathrm{m}$ using a sliding microtome (Microm HM440E; Carl Zeiss AG, Oberkochen, Germany). Bone growth was determined by measuring the gap between the fluorescent line formed by calcein and the diaphyseal line of the growth plate with a fluorescence microscope (BX60; Olympus Corporation, Tokyo, Japan). Mean bone growth was calculated on the basis of measurements obtained from three random places. Cresyl violet staining (Sigma-Aldrich; Merck $\mathrm{KGaA}$ ) was performed to stain the growth plate, and the mean growth plate height was calculated on the basis of measurements obtained from three random locations.

Laser microdissection (LMD). A 30- $\mu \mathrm{m}$ thick section prepared from the frozen tibia was mounted onto slides (Jungwoo F\&B Corp., Incheon, Korea). Two fragments (proliferative and hypertrophic zone) of growth plate tissues were collected separately in $0.5-\mathrm{ml}$ tube caps using an ION LMD system (R2.1; Jungwoo F\&B Corp.).

Reverse transcription-quantitative polymerase chain reaction $(R T-q P C R)$. Total RNA was extracted from the microdissected tissues using an RNeasy ${ }^{\circledR}$ Protect Mini kit (Qiagen, Inc., Valencia, CA, USA), in accordance with the manufacturer's protocol. cDNA was then synthesized from the mRNA using a QuantiTect ${ }^{\circledR}$ Reverse Transcription kit (Qiagen, Inc.) and qPCR was performed with a QuantiTectTM SYBR ${ }^{\circledR}$-Green PCR kit (Qiagen, Inc.), in accordance with manufacturer's protocols. The kit HotStarTaq DNA polymerase was activated by an initial heating activation step for $15 \mathrm{~min}$ at $95^{\circ} \mathrm{C}$, followed by 40 cycles of denaturation at $94^{\circ} \mathrm{C}$ for $15 \mathrm{sec}$, annealing at $60^{\circ} \mathrm{C}$ for $15 \mathrm{sec}$ and extension at $72^{\circ} \mathrm{C}$ for $20 \mathrm{sec}$. The PCR primer sequences are presented in Table I. PCR was performed using a Rotor-Gene $\mathrm{Q}^{\circledast}$ (Qiagen, Inc.) according to the manufacturer's protocol. The quantities of mRNA were calculated relative to that of GAPDH, based on the $\Delta \Delta \mathrm{C}_{\mathrm{q}}$ method (24).

Detection of IGF-1 protein expression in the growth plate. To detect the expression of IGF-1 in the growth plate, dehydrated tibia sections were incubated overnight in $1 \%$ Triton-X-100 containing rabbit IGF-1 antibody (sc-9013; Santa Cruz Biotechnology, Inc., Dallas, TX, USA; 1:500) at room temperature. The sections were then incubated with anti-rabbit antibody (F0382; Sigma-Aldrich; Merck KGaA; $1: 200$ ) for $60 \mathrm{~min}$ at room temperature and stained with 
Table I. Primer sequences used for quantitative polymerase chain reaction.

Sequence, $5^{\prime}$ to $3^{\prime}$

\begin{tabular}{llc}
\cline { 2 - 2 } mRNA & \multicolumn{1}{c}{ Forward } & \multicolumn{1}{c}{ Reverse } \\
\hline GAPDH & CTC CCT GTT CTA GAG ACA & CCA TGT AGT TGA GGT CAA \\
IGF-1 & CCT CCA ATA AAG ATA CAC ATC & TGG GCT TGT TGA AGT AAA \\
GHR & GGA GAT TTA TAT ACC CAA GC & GCT AGG GTT GAAAGT AGA \\
IGF-1R & CCT GTG AAA GTG ATG TTC & CCT TGT AGT AGA CTG TGA A
\end{tabular}

GAPDH, glyceraldehyde 3-phosphate dehydrogenase; IGF-1, insulin-like growth factor 1; GHR, growth hormone receptor; IGF-1R, IGF-1 receptor.

0.05\% 3,3-diaminobenzidine (Sigma-Aldrich; Merck KGaA) containing $0.03 \%$ hydrogen peroxide. Images of slides were obtained with a fluorescence microscope and the density was measured using ImageJ software (version 1.48; National Institutes of Health, Bethesda, MD, USA).

Statistical analysis. Data are expressed as the mean \pm standard error of the mean. One-way analysis of variance followed by Tukey's post hoc test was performed for statistical analysis with GraphPad Prism (version 6; GraphPad Software, Inc.). $\mathrm{P}<0.05$ was considered to indicate a statistically significant difference.

\section{Results}

Identification of the median effective dose (ED50) of DXM on longitudinal bone growth retardation. A preliminary experiment was performed to determine the ED50 of DXM on bone growth depression in adolescent male rats. A range of dosages of DXM were administered subcutaneously: 0, 0.5, 1, 2 and $5 \mathrm{mg} / \mathrm{kg}$. The inhibitory effect of DXM on the growth rate of longitudinal bone from the proximal growth plate of tibias in the rats is depicted in Fig. 1A. The fluorescent line corresponded to the injection of the calcium-binding agent calcein (Fig. 1A, lower arrow). The height between the fluorescent line formed by calcein and the diaphyseal line of the growth plate (Fig. 1A, upper arrow) indicated the extent to which the bone had grown in $24 \mathrm{~h}$. Longitudinal bone growth was significantly decreased in a dose-dependent manner by DXM treatment $(\mathrm{P}<0.05$; Fig. 1B). The heights measured at a DXM dosage of $0.5,1,2$ and $5 \mathrm{mg} / \mathrm{kg}$ were $383.4 \pm 12.5,341.5 \pm 7.1,227.7 \pm 9.8$ and $190.8 \pm 10.5 \mu \mathrm{m}$, respectively $(85.3 \pm 2.9,75.9 \pm 1.6,50.6 \pm 2.2$ and $42.4 \pm 2.3 \%$ of the control, respectively). The calculated ED50 value was $1.15 \mathrm{mg} / \mathrm{kg}$. Furthermore, the weight of rats was reduced in a dose-dependent manner ( $\mathrm{P}<0.05$; Fig. 2).

Effect of GH on DXM-induced GI of the longitudinal bone and growth plate. To evaluate the effect of GH on GI induced by DXM, GH was administered to rats with $1.15 \mathrm{mg} / \mathrm{kg}$ (ED50) DXM. The body weight of rats increased in both the control and $\mathrm{GH}$ alone groups, and no significant difference was observed between the two groups. All DXM-treated groups exhibited significantly lower body weights than the control and $\mathrm{GH}$ alone groups $(\mathrm{P}<0.05)$. Furthermore, the body weights of rats in the DXM-treated groups decreased at a similar rate, regardless of the GH dosage administered. Thus, GH administration did not appear to prevent weight loss induced by DXM (Fig. 3).

Effect of GH on longitudinal bone growth. Relative to the control group, $\mathrm{GH}$ administration alone significantly increased longitudinal bone growth in rats $(\mathrm{P}<0.05$; Fig. 4). The longitudinal bone at $\mathrm{GH}$ dosages of 0 (control) and $2.5 \mathrm{mg} / \mathrm{kg}(\mathrm{GH}$ alone) increased by $494.9 \pm 9.6$ and $551.0 \pm 15.9 \mu \mathrm{m}(111.5 \pm 3.2 \%$ of the control), respectively. In addition, treatment with $\mathrm{GH}$ increased longitudinal bone growth in DXM-treated rats; an effect deemed to be significant for 2.5 and $5 \mathrm{mg} / \mathrm{kg} \mathrm{GH}$ $(\mathrm{P}<0.05)$. The longitudinal bones of DXM-treated rats $(1.15 \mathrm{mg} / \mathrm{kg}$ ) following $\mathrm{GH}$ dosages of $2.5,5$ and $10 \mathrm{mg} / \mathrm{kg}$ increased by $349.1 \pm 10.1,354.2 \pm 11.9$ and $323.1 \pm 20.2 \mu \mathrm{m}$, respectively $(111.3 \pm 4.4,112.9 \pm 3.8$ and $103.0 \pm 6.4 \%$ of the control, respectively; Fig. 4).

Effect of GH on growth plate height. The effect of GH on the height of the proximal growth plate is depicted in Fig. 5A. The height between the resting zone (Fig. 5A, upper arrow) and the diaphyseal line of the growth plate (Fig. 5A, lower arrow) indicated the height of the growth plate. Relative to the control group, $\mathrm{GH}$ administration alone significantly increased the height of the growth plate $(\mathrm{P}<0.05$; Fig. 5B). The growth plate height at $\mathrm{GH}$ dosages of 0 (control) and $2.5 \mathrm{mg} / \mathrm{kg}$ (GH alone) increased by $577.5 \pm 17.0$ and $627.8 \pm 18.2 \mu \mathrm{m}(108.7 \pm 3.1 \%$ of the control), respectively. In addition, treatment with $\mathrm{GH}$ increased growth plate height in DXM-treated rats; an effect deemed to be significant for 2.5 and $5 \mathrm{mg} / \mathrm{kg} \mathrm{GH}(\mathrm{P}<0.05)$. The growth plate height in DXM-treated rats $(1.15 \mathrm{mg} / \mathrm{kg})$ following $\mathrm{GH}$ dosages of 0 (control), 2.5, 5 and $10 \mathrm{mg} / \mathrm{kg}$ increased by $343.9 \pm 8.1,386.7 \pm 11.8,404.5 \pm 11.4$ and $373.3 \pm 23.2 \mu \mathrm{m}$, respectively $(112.5 \pm 3.4,117.6 \pm 3.3$ and $108.6 \pm 6.7 \%$ of the control, respectively).

Effect of GH on IGF-1 expression in the growth plate of rats. The expression of IGF-1 in the proliferative and hypertrophic zones of the growth plate in the control, GH alone $(2.5 \mathrm{mg} / \mathrm{kg})$, DXM alone $(1.15 \mathrm{mg} / \mathrm{kg})$ and DXM + GH $(1.15+2.5 \mathrm{mg} / \mathrm{kg}$, respectively) groups was assessed. LMD followed by qPCR and antigen-specific immunohistochemistry were used to measure IGF-1 expression at the mRNA and protein levels, 
A

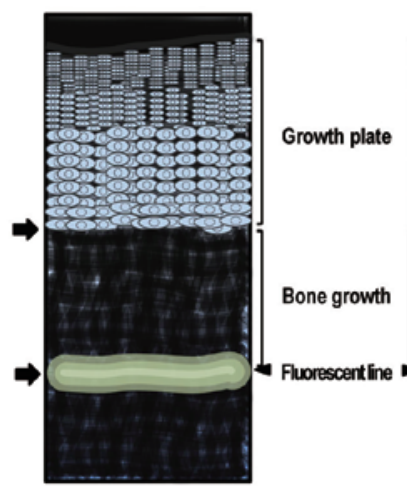

B

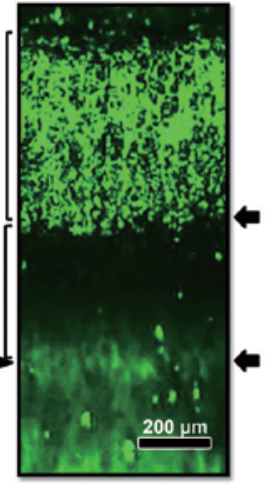

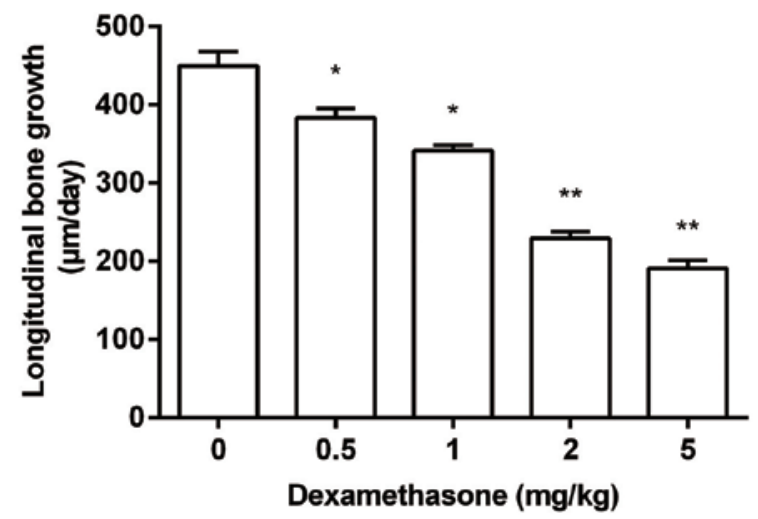

Figure 1. Effect of DXM on longitudinal bone growth. (A) Schematic diagram (left) and fluorescence photomicrograph (right) of a longitudinal section of the proximal tibia $(0 \mathrm{mg} / \mathrm{kg}$ group). The fluorescent line corresponded to the injection of the calcium-binding agent calcein (lower arrow). The height between the fluorescent line formed by calcein and the diaphyseal line of the growth plate (upper arrow) indicated the extent to which the bone had grown in $24 \mathrm{~h}$ (B) Effects of DXM $(0,0.5,1,2$ or $5 \mathrm{mg} / \mathrm{kg})$ on longitudinal bone growth. ${ }^{*} \mathrm{P}<0.05,{ }^{* *} \mathrm{P}<0.01 \mathrm{vs} .0 \mathrm{mg} / \mathrm{kg}$. DXM, dexamethasone.

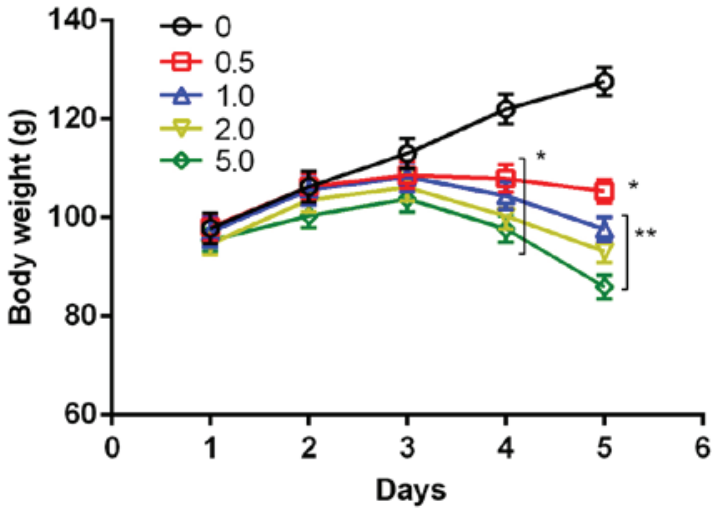

Figure 2. Body weight changes in DXM-treated adolescent male rats. DXM $(0,0.5,1,2$ or $5 \mathrm{mg} / \mathrm{kg})$ was subcutaneously administered. ${ }^{*} \mathrm{P}<0.05,{ }^{* *} \mathrm{P}<0.01$ vs. $0 \mathrm{mg} / \mathrm{kg}$. DXM, dexamethasone.

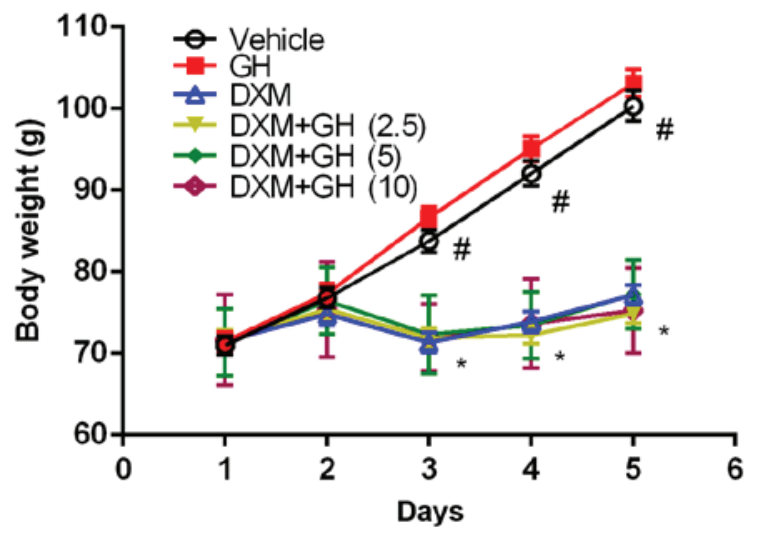

Figure 3. Body weight changes in adolescent male rats administered with GH and/or DXM. GH $(2.5,5$ or $10 \mathrm{mg} / \mathrm{kg})$ and/or DXM $(1.15 \mathrm{mg} / \mathrm{kg})$ were administered subcutaneously. ${ }^{*} \mathrm{P}<0.05$ vs. vehicle, ${ }^{*} \mathrm{P}<0.05$ vs. DXM. DXM dexamethasone; $\mathrm{GH}$, growth hormone.

respectively. In the total area, the expression of IGF-1 mRNA in the GH alone group was significantly increased compared with the control group $(10.9 \pm 3.2$ vs. $1.0 \pm 0.7$; P<0.05; Fig. 6A). Levels of IGF-1 mRNA were also significantly increased in

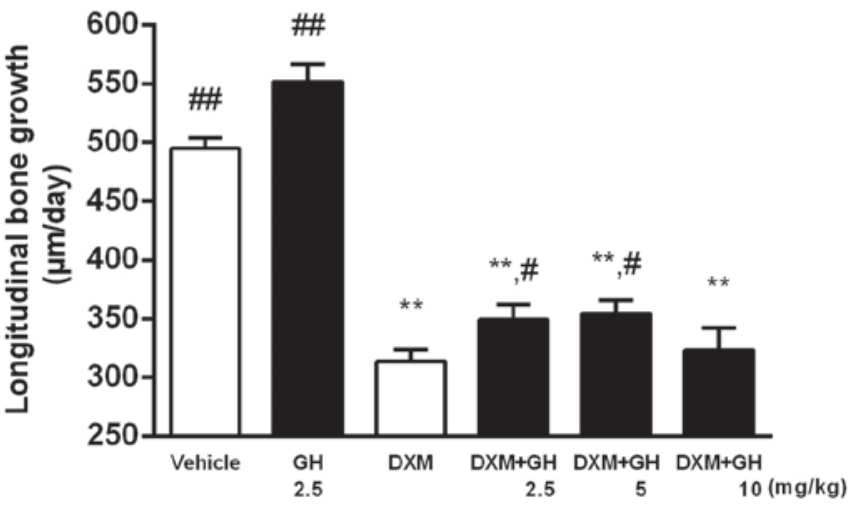

Figure 4. Effect of GH and DXM on longitudinal bone growth in adolescent male rats. The effect of GH $(2.5,5$ and $10 \mathrm{mg} / \mathrm{kg})$ on longitudinal bone growth retardation induced by DXM $(1.15 \mathrm{mg} / \mathrm{kg})$ was measured. ${ }^{* * *} \mathrm{P}<0.01$ vs. vehicle; ${ }^{\#} \mathrm{P}<0.05,{ }^{\# \#} \mathrm{P}<0.01$ vs. DXM. DXM, dexamethasone; $\mathrm{GH}$, growth hormone.

the DXM + GH group when compared with the DXM group (8.9 \pm 3.6 vs. $0.9 \pm 0.6 ; \mathrm{P}<0.05$; Fig. $6 \mathrm{~A}$ ).

In the proliferative zone, the expression of IGF-1 mRNA in the $\mathrm{GH}$ alone group was significantly increased compared with the control group (17.8 \pm 10.0 vs. $1.0 \pm 0.8$; $\mathrm{P}<0.05$, Fig. $6 \mathrm{~B})$. However, IGF-1 mRNA was not significantly increased in the DXM + GH group when compared with the DXM group (Fig. 6B).

In the hypertrophic zone, expression of IGF-1 mRNA in the GH alone group was not significantly increased compared with the control group (Fig. 6C). However, IGF-1 mRNA was significantly increased in the DXM $+\mathrm{GH}$ group when compared with the DXM group $(14.7 \pm 6.7$ vs. $1.0 \pm 0.7 ; \mathrm{P}<0.05$; Fig. 6C).

In the proliferative zone, expression of IGF-1 protein in the $\mathrm{GH}$ alone group was significantly increased to $206.5 \pm 8.5 \%$, relative to the control group $(\mathrm{P}<0.05$; Fig. 7A). However, levels of IGF-1 protein in the DXM + GH group were not significantly increased compared with the DXM group.

In the hypertrophic zone, IGF-1 protein in the GH alone group was significantly increased to $193.1 \pm 8.9 \%$ relative to the 
A

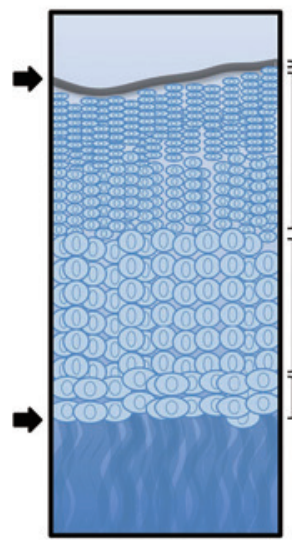

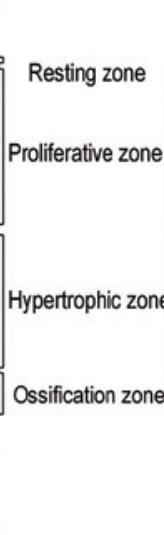

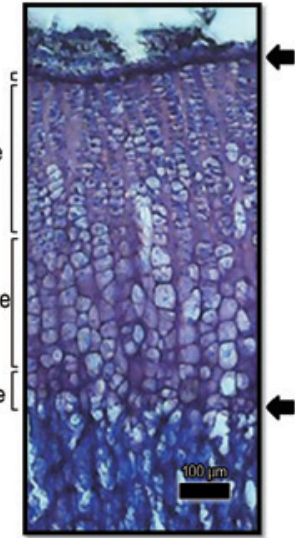

\section{B}

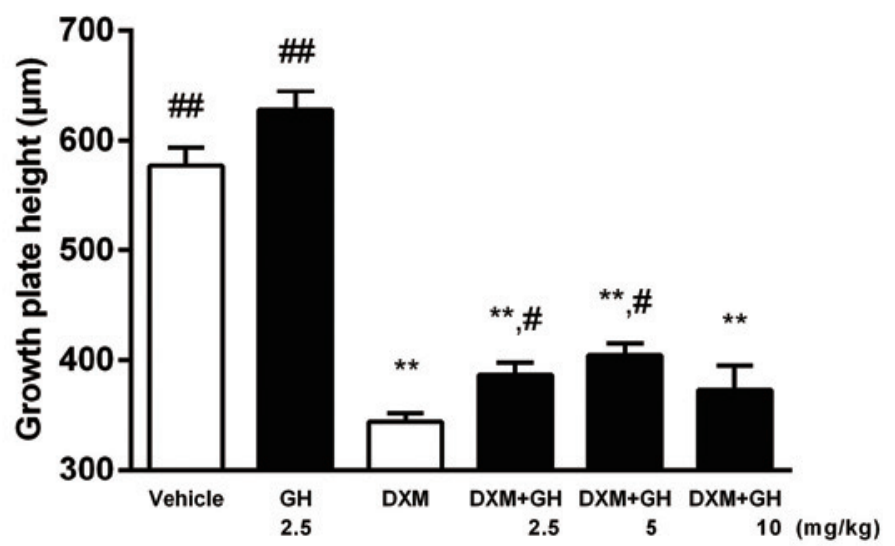

Figure 5. Effect of GH and/or DXM treatment on growth plate height. (A) Schematic diagram (left) and photomicrograph (right) of a longitudinal section of the proximal growth plate. The height between the resting zone (upper arrow) and the diaphyseal line of the growth plate (lower arrow) indicates the height of the growth plate. (B) Effect of GH (2.5, 5 and $10 \mathrm{mg} / \mathrm{kg})$ on growth plate height reduction induced by DXM $(1.15 \mathrm{mg} / \mathrm{kg}){ }^{* * *} \mathrm{P}<0.01 \mathrm{vs}$. vehicle; ${ }^{*} \mathrm{P}<0.05$ and ${ }^{\#} \mathrm{P}<0.01$ vs. DXM. DXM, dexamethasone; GH, growth hormone.
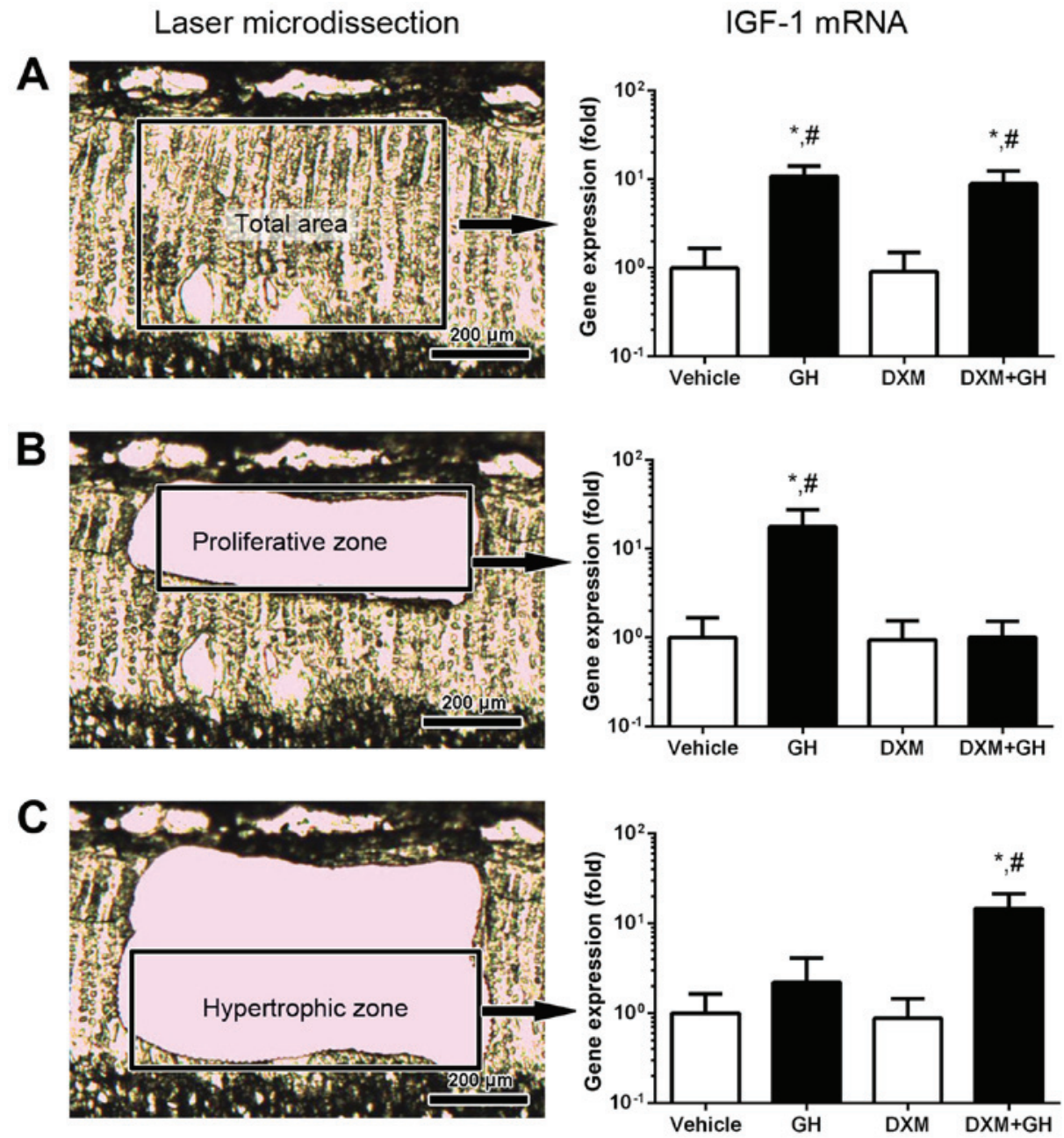

Figure 6. Laser microdissection of the growth plate of a tibial bone and analysis of IGF-1 mRNA expression. IFG-1 expression was evaluated in the (A) whole area, (B) proliferative zone and (C) hypertrophic zone after treatment with GH and/or DXM. ${ }^{*} \mathrm{P}<0.05$ vs. vehicle; ${ }^{*} \mathrm{P}<0.05$ vs. DXM. IGF-1, insulin-like growth factor 1; DXM, dexamethasone; GH, growth hormone.

control group ( $\mathrm{P}<0.05$, Fig. 7B). IGF-1 protein in the DXM + GH group was increased to a small degree compared with the DXM group; however, no significant difference was observed.
Effect of GH on GHR and IGF-1R expression in the growth plate of rats. The expressions of GHR and IGF-1R mRNA in the proliferative and hypertrophic zones of the growth plate 


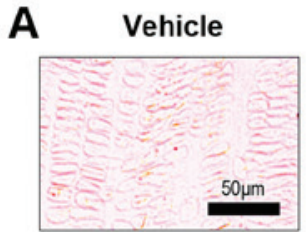

Proliferative zone

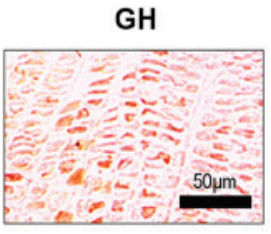

B

Hypertrophic zone

\begin{abstract}
Proliferative zone
\end{abstract}
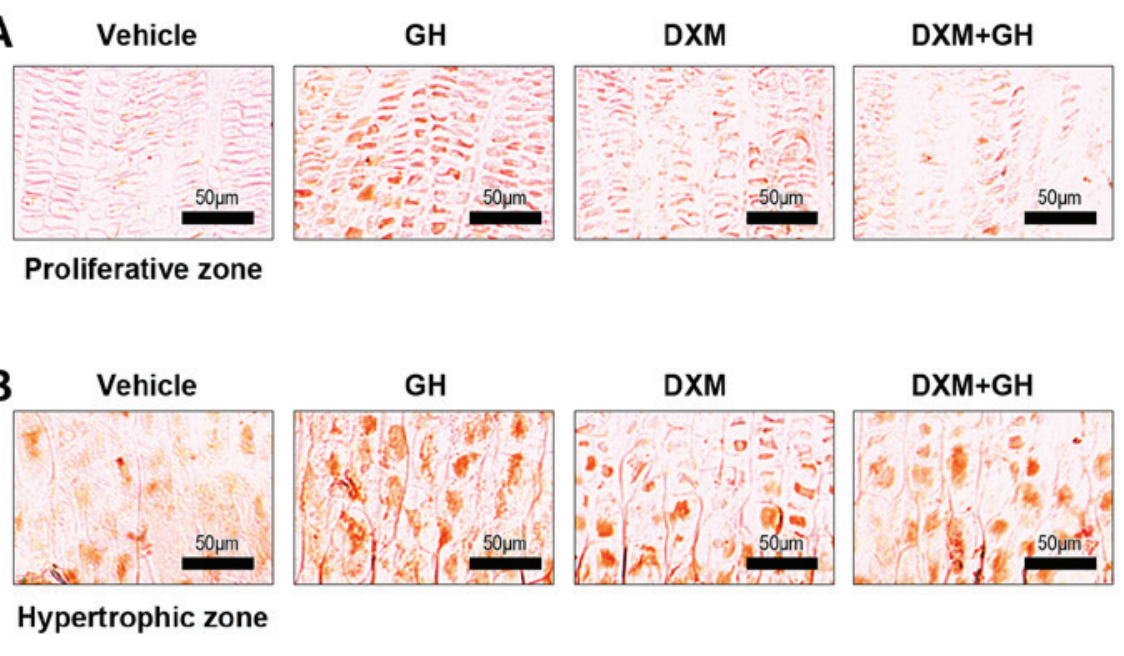

$50 \mathrm{~mm}$
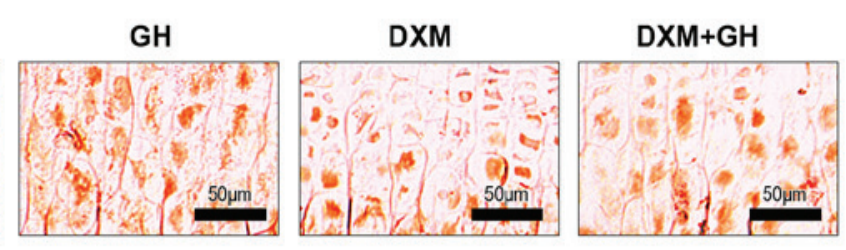

Figure 7. Immunohistochemical localization of IGF-1 in the growth plate. IGF-1 expression was evaluated in the (A) proliferative zone and (B) hypertrophic zone after treatment with GH and/or DXM. Densitometric results of immunohistochemistry were presented in a bar graph. " $\mathrm{P}<0.05$ vs. vehicle; " $\mathrm{P}<0.05$ vs. DXM. IGF-1, insulin-like growth factor 1; DXM, dexamethasone; GH, growth hormone.

\section{A}

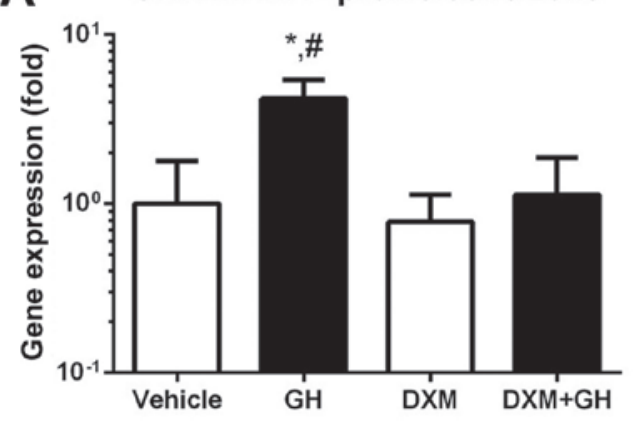

B GHR mRNA - hypertropic zone

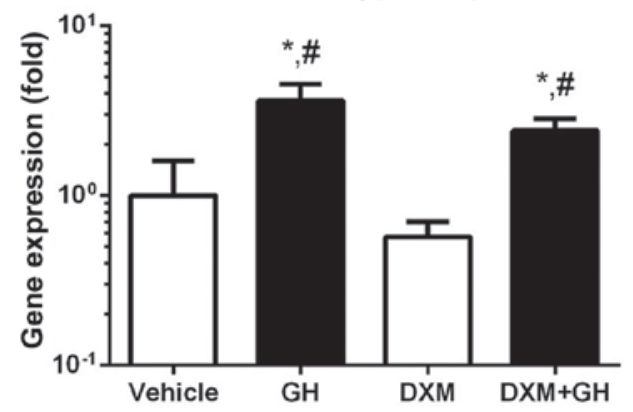

\section{IGF-1R mRNA - proliferative zone}

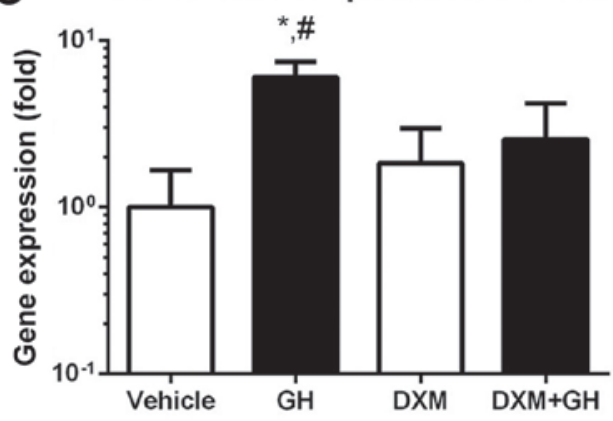

D

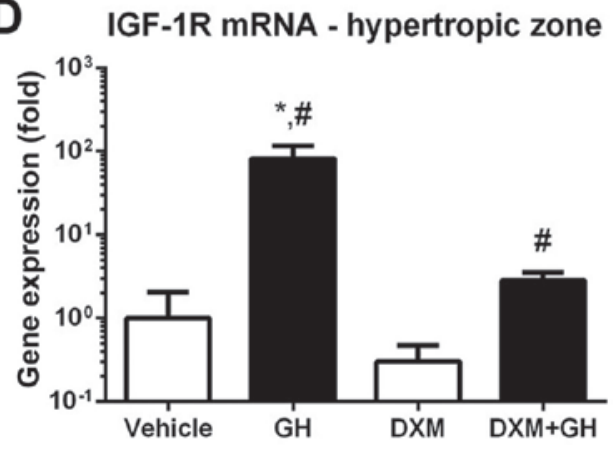

Figure 8. Effect of GH and/or DXM treatment on GHR and IGF-1R mRNA expression in the growth plate. Expression of GHR in the (A) proliferative zone and (B) hypertrophic zone, and expression of IGF-1R in the (C) proliferative zone and (D) hypertrophic zone after treatment with GH and/or DXM. ${ }^{*} \mathrm{P}<0.05$ vs. vehicle, ${ }^{\#} \mathrm{P}<0.05$ vs. DXM. DXM, dexamethasone; GH, growth hormone; GHR, GH receptor; IGF-1R, insulin-like growth factor 1 receptor.

in the control, GH alone, DXM alone and DXM + GH groups were measured to evaluate DXM-induced GH insensitivity in the growth plate.

In the proliferative zone, the expression of GHR mRNA in the $\mathrm{GH}$ alone group was significantly increased compared with the control group ( $4.2 \pm 1.2$ vs. $1.0 \pm 0.8$; $\mathrm{P}<0.05$; Fig. $8 \mathrm{~A})$. However, GHR mRNA in the DXM + GH group was not significantly increased compared with the DXM group (Fig. 8A).

In the hypertrophic zone, GHR mRNA in the GH alone group was significantly increased compared with the control group (3.6 \pm 0.9 vs. $1.0 \pm 0.6 ; \mathrm{P}<0.05$, Fig. $8 \mathrm{~B})$. GHR mRNA was also significantly increased in the DXM + GH group when compared with the DXM group (2.4 \pm 0.4 vs. $0.6 \pm 0.1$; $\mathrm{P}<0.05$; Fig. $8 \mathrm{~B})$.

In the proliferative zone, expression of IGF-1R mRNA in the $\mathrm{GH}$ alone group was significantly increased compared with the control group $(6.0 \pm 1.4$ vs. $1.0 \pm 0.7 ; \mathrm{P}<0.05$; Fig. $8 \mathrm{C})$. However, IGF-1R mRNA in the DXM + GH group was not significantly increased when compared with the DXM group (Fig. 8C).

In the hypertrophic zone, IGF-1R mRNA in the GH alone group was significantly increased compared with the control group $(82.2 \pm 33.8$ vs. $1.0 \pm 1.0 ; \mathrm{P}<0.05$; Fig. $8 \mathrm{D})$. IGF-1R mRNA was also significantly increased in the DXM + GH group 
compared with the DXM group ( $2.8 \pm 0.7$ vs. $0.3 \pm 0.2 ; \mathrm{P}<0.05$; Fig. 8D).

\section{Discussion}

In a preliminary experiment to determine the ED50 of DXM on the GI of longitudinal bone, DXM administration led to decreases in longitudinal bone growth and the body weight of rats in a dose-dependent manner. These results were concordant with a previous in vivo study (5), which indicated that DXM exerted a direct growth-inhibitory effect on the growth plate. At low concentrations, GCs increase the secretion of GH by increasing levels of GH releasing hormone (GHRH), while at high concentrations of GCs, a decrease in the release of GHRH has been reported (25). High-dose and long-term GC therapy may inflict GI on children (26), and an overdose of DXM above the usual physiological levels has been reported to consistently suppress levels of GH in the serum (27). Furthermore, it has been observed that even short-term DXM treatment of mice (for 7 days) caused significant growth failure and decreased the height of the growth plate (11).

The growth plate is a hyaline cartilage plate with a disc-like structure interposed between the epiphysis and metaphysis of a long bone. It consists of three well-defined anatomic zones: The resting zone, proliferative zone and hypertrophic zone $(28,29)$. GH promotes local secretion of IGF-1, thereby stimulating proliferation of chondrocytes in the proliferative zone (30). Thus, in the present study, a follow-up investigation was implemented under the assumption that exogenous GH administration may ameliorate or attenuate DXM-induced GI. The present results indicated that GH did not prevent DXM-induced body weight loss, though partially counteracted the DXM-induced GI of longitudinal bone in a subsequent in vivo experiment. However, the recovery effect of GH on DXM-induced bone growth retardation was insufficient. GH exhibited a similar level of growth promoting effect $(\sim 11 \%)$ at a dose of $2.5 \mathrm{mg} / \mathrm{kg}$ with or without DXM, but failed to neutralize DXM-induced GI.

IGF-1 is a single chain protein secreted systemically by the liver as an endocrine hormone and locally in target tissues as a paracrine and/or autocrine factor (31). IGF-1, the production of which is induced by GH, serves a vital role in childhood growth and exerts anabolic effects in adults and acts systemically through the circulation and locally in an autocrine and/or paracrine manner (32). The effects of GH are primarily mediated through the production of IGF-1; hence, IGF-1 is recognized as a key regulator of bone growth, development and metabolism (33). In a previous study, disruption of IGF-1 in chondrocytes resulted in decreased bone length and width (34). Locally secreted IGF-1 in the growth plate is necessary for proper organization and function of the growth plate, and may be more critical in the growth plate than circulating factors $(35,36)$. Therefore, in the current study, the effect of GH on the mRNA and protein expression of IGF-1 in the growth plate was evaluated using qPCR and immunohistochemistry. The results indicated that GH ameliorated the DXM-induced downregulation of IGF-1 mRNA in the hypertrophic zone, while exerting no effect in the proliferative zone. The quantity of IGF-1 protein in the proliferative zone of DXM-treated rats decreased despite GH administration, but its amount in the hypertrophic zone increased to a small degree with $\mathrm{GH}$ administration. However, GH exerted incomplete recovery effects on the expression of IGF-1 in the growth plate. These results were concordant with a previous study (37), in which DXM primarily exerted an inhibitory effect on proliferative chondrocytes in the growth plate. Thus, the present study suggests that GH insensitivity in chondrocytes of the proliferative zone may be induced by DXM, while GH insensitivity in chondrocytes of the hypertrophic zone does not arise or is induced insufficiently. The data also suggests that exogenous administration of GH does not prevent DXM-induced growth retardation. However, the elevation of IGF-1 protein of DXM and DXM + GH groups in the hypertrophic zone could be considered a limitation of the present study, thus further examination needs to be performed.

DXM-induced GI results from increased insensitivity to GH and IGF-1. This is caused by inhibition of endogenous GH secretion by DXM, which perturbs the GH-IGF-1 axis, and by DXM blocking the activation of GHR and IGF-1R in chondrocytes of the growth plate (38). Accordingly, the current study evaluated DXM-induced insensitivity to GH in the growth plate by measuring the expression of GHR and IGF-1R mRNA with qPCR. The results indicated that GH ameliorated the DXM-induced downregulation of GHR and IGF-1R mRNA in the hypertrophic zone, while exerting no effects in the proliferative zone. Similarly, Heinrichs et al (39) reported that GHR mRNA levels in the growth plate did not increase following high-dose administration of DXM $(4 \mathrm{mg} / \mathrm{kg}$ per day). An in vitro study using cultured rat chondrocytes also identified a time-dependent downregulation of GHR mRNA induced by treatment with DXM, leading to downregulation of GH-stimulated expression of GHR (10). Furthermore, results of the current in vivo experiments demonstrated that IGF-1, GHR and IGF-1R mRNA levels in the proliferative zone of the growth plate were unresponsive to exogenous $\mathrm{GH}$ administration, thus indicating that increased insensitivity to $\mathrm{GH}$ in chondrocytes of the proliferative zone directly leads to DXM-induced GI. Further experiments are now warranted to determine the mechanism by which GH affects the proliferative chondrocytes of the growth plate.

In conclusion, GH administration incompletely recovered DXM-induced GI of the growth plate and longitudinal bones. GH augmented the levels of IGF-1, GHR and IGF-1R mRNA in the proliferative zone of the vehicle group, but failed to upregulate the mRNAs in the proliferative zone of DXM-treated groups. GH also increased the expression of IGF-1, GHR and IGF-1R mRNA in the hypertrophic zone of both the vehicle and DXM-treated groups. The immunohistochemical analysis of IGF-1 protein expression exhibited a similar pattern to that of IGF-1 mRNA. These results suggest that DXM-induced GH insensitivity in the proliferative zone of the growth plate results in GI in longitudinal bones. However, administration of exogenous $\mathrm{GH}$ was unable to counteract DXM-induced GI. Thus, combined administration of GH with GH insensitivity-alleviating medications may be more effective in the treatment of DXM-induced GI.

\section{Acknowledgements}

The present study was supported by Semyung University, Jecheon, Republic of Korea (project no. 2016-20030023). 


\section{References}

1. Sissons HA and Hadfield GJ: The influence of cortisone on the structure and growth of bone. J Anat 89: 69-78, 1955.

2. Bechtold S and Roth J: Natural history of growth and body composition in juvenile idiopathic arthritis. Horm Res 72 (Suppl 1): S13-S19, 2009.

3. Griffiths AM: Growth retardation in early-onset inflammatory bowel disease: Should we monitor and treat these patients differently? Dig Dis 27: 404-411, 2009.

4. Sanderson IR: Growth problems in children with IBD. Nat Rev Gastroenterol Hepatol 11: 601-610, 2014.

5. Baron J, Huang Z, Oerter KE, Bacher JD and Cutler GB Jr: Dexamethasone acts locally to inhibit longitudinal bone growth in rabbits. Am J Physiol 263: E489-E492, 1992.

6. Olympia RP, Khine H and Avner JR: Effectiveness of oral dexamethasone in the treatment of moderate to severe pharyngitis in children. Arch Pediatr Adolesc Med 159: 278-282, 2005.

7. Roy M, Bailey B, Amre DK, Girodias JB, Bussières JF and Gaudreault P: Dexamethasone for the treatment of sore throat in children with suspected infectious mononucleosis: A randomized, double-blind, placebo-controlled, clinical trial. Arch Pediatr Adolesc Med 158: 250-254, 2004.

8. World Health Organization: 19th WHO model list of essential medicines, 2015

9. Altman A, Hochberg Z and Silbermann M: Interactions between growth hormone and dexamethasone in skeletal growth and bone structure of the young mouse. Calcif Tissue Int 51: 298-304, 1992.

10. Jux C, Leiber K, Hügel U, Blum W, Ohlsson C, Klaus G and Mehls O: Dexamethasone impairs growth hormone $(\mathrm{GH})$-stimulated growth by suppression of local insulin-like growth gactor (IGF)-I production and expression of GH-and IGF-I-receptor in cultured rat chondrocytes. Endocrinology 139: 3296-3305, 1998.

11. Smink JJ, Gresnigt MG, Hamers N, Koedam JA, Berger R and Van Buul-Offers SC: Short-term glucocorticoid treatment of prepubertal mice decreases growth and IGF-I expression in the growth plate. J Endocrinol 177: 381-388, 2003.

12. Lui JC, Nilsson O and Baron J: Growth plate senescence and catch-up growth. Endocr Dev 21: 23-39, 2011.

13. Lui JC and Baron J: Effects of glucocorticoids on the growth plate. In: Pediatric Adrenal Diseases. Karger Publishers, pp187-193, 2011.

14. Karimian E, Chagin AS and Sävendahl L: Genetic regulation of the growth plate. Front Endocrinol (Lausanne) 2: 113, 2012.

15. Bierich JR: Multicentre clinical trial of authentic recombinant somatropin in growth hormone deficiency. Acta Paediatr Scand Suppl 337: 135-140, 1987.

16. Krysiak R, Gdula-Dymek A, Bednarska-Czerwińska A and Okopień B: Growth hormone therapy in children and adults Pharmacol Rep 59: 500-516, 2007.

17. Vance ML and Mauras N: Growth hormone therapy in adults and children. N Engl J Med 341: 1206-1216, 1999.

18. Allen DB and Goldberg BD: Stimulation of collagen synthesis and linear growth by growth hormone in glucocorticoid-treated children. Pediatrics 89: 416-421, 1992.

19. Sarna S, Sipilä I, Rönnholm K, Koistinen R and Holmberg C: Recombinant human growth hormone improves growth in children receiving glucocorticoid treatment after liver transplantation. J Clin Endocrinol Metab 81: 1476-1482, 1996.

20. Savage M, Simon D and Czernichow P: Growth hormone treatment in children on chronic glucorticoid therapy. In: Pediatric Adrenal Diseases. Karger Publishers, pp194-201, 2010.

21. Touati G, Prieur AM, Ruiz JC, Noel M and Czernichow P: Beneficial effects of one-year growth hormone administration to children with juvenile chronic arthritis on chronic steroid therapy. I. Effects on growth velocity and body composition. J Clin Endocrinol Metab 83: 403-409, 1998.
22. Allen DB, Julius JR, Breen TJ and Attie KM: Treatment of glucocorticoid-induced growth suppression with growth hormone. National Cooperative Growth Study. J Clin Endocrinol Metab 83: 2824-2829, 1998.

23. Hansson LI, Menander-Sellman K, Stenström A and Thorngren KG: Rate of normal longitudinal bone growth in the rat. Calcif Tissue Res 10: 238-251, 1972.

24. Livak KJ and Schmittgen TD: Analysis of relative gene expression data using real-time quantitative PCR and the 2(-Delta Delta C(T)) method. Methods 25: 402-408, 2001.

25. Fife SK, Brogan RS, Giustina A and Wehrenberg WB: Immunocytochemical and molecular analysis of the effects of glucocorticoid treatment on the hypothalamic-somatotropic axis in the rat. Neuroendocrinology 64: 131-138, 1996.

26. Burguera B, Muruais C, Peñalva A, Dieguez C and Casanueva FF: Dual and selective actions of glucocorticoids upon basal and stimulated growth hormone release in man. Neuroendocrinology 51: 51-58, 1990.

27. Nakagawa K, Ishizuka T, Obara T, Matsubara M and Akikawa K: Dichotomic action of glucocorticoids on growth hormone secretion. Acta Endocrinol (Copenh) 116: 165-171, 1987.

28. Hunziker EB: Mechanism of longitudinal bone growth and its regulation by growth plate chondrocytes. Microsc Res Tech 28: 505-519, 1994.

29. Ballock RT and O'Keefe RJ: The biology of the growth plate. J Bone Joint Surg Am 85: 715-726, 2003.

30. Wong SC, Dobie R, Altowati MA, Werther GA, Farquharson C and Ahmed SF: Growth and the growth hormone-insulin like growth factor 1 axis in children with chronic inflammation: current evidence, gaps in knowledge and future directions. Endocr Rev 37: 62-110, 2015.

31. Kaplan SA and Cohen P: The somatomedin hypothesis 2007: 50 years later. J Clin Endocrinol Metab 92: 4529-4535, 2007.

32. Mohan S and Kesavan C: Role of insulin-like growth factor-1 in the regulation of skeletal growth. Curr Osteoporos Rep 10: 178-186, 2012.

33. Locatelli V and Bianchi VE: Effect of GH/IGF-1 on bone metabolism and osteoporsosis. Int J Endocrinol 2014: 235060, 2014.

34. Govoni KE, Lee SK, Chung YS, Behringer RR, Wergedal JE, Baylink DJ and Mohan S: Disruption of insulin-like growth factor-I expression in type IIalphaI collagen-expressing cells reduces bone length and width in mice. Physiol Genomics 30: 354-362, 2007.

35. Wang Y, Cheng Z, ElAlieh HZ, Nakamura E, Nguyen MT, Mackem S, Clemens TL, Bikle DD and Chang W: IGF-1R signaling in chondrocytes modulates growth plate development by interacting with the $\mathrm{PTHrP} / \mathrm{Ihh}$ pathway. J Bone Miner Res 26: 1437-1446, 2011.

36. Sjögren K, Liu JL, Blad K, Skrtic S, Vidal O, Wallenius V, LeRoith D, Törnell J, Isaksson OG, Jansson JO and Ohlsson C: Liver-derived insulin-like growth factor I (IGF-I) is the principal source of IGF-I in blood but is not required for postnatal body growth in mice. Proc Natl Acad Sci USA 96: 7088-7092, 1999.

37. Gafni RI, Weise M, Robrecht DT, Meyers JL, Barnes KM, De-Levi S and Baron J: Catch-up growth is associated with delayed senescence of the growth plate in rabbits. Pediatr Res 50: 618-623, 2001.

38. MacRae VE, Ahmed SF, Mushtaq T and Farquharson C: IGF-I signalling in bone growth: Inhibitory actions of dexamethasone and IL-1beta. Growth Horm IGF Res 17: 435-439, 2007.

39. Heinrichs C, Yanovski JA, Roth AH, Yu YM, Domené HM, Yano K, Cutler GB Jr and Baron J: Dexamethasone increases growth hormone receptor messenger ribonucleic acid levels in liver and growth plate. Endocrinology 135: 1113-1118, 1994. 